\title{
Impact of soil treatment on internal erosion resistance and hydro- mechanical characteristics of a silty soil
}

\author{
A. Mehenni \\ Bouygues Travaux Publics, Guyancourt, France \\ LEMTA, UMR 7563 CNRS - Université de Lorraine, Vandoeuvre-les-Nancy, France \\ O. Cuisinier \& F. Masrouri \\ LEMTA, UMR 7563 CNRS - Université de Lorraine, Vandoeuvre-les-Nancy, France \\ E. Lavallée \\ Bouygues Travaux Publics, Guyancourt, France
}

\begin{abstract}
The aim of this paper is to examine the impact of soil treatment on the internal erosion and the hydro-mechanical characteristics of a silty soil. The study is focused on the treatment by kaolinite, bentonite, lime and cement, with different amounts and curing periods. A new enhanced Hole Erosion Test was developed especially to study the internal erosion of treated soils using high hydraulic shear stresses.

The use of clayey products decreases both the hydraulic conductivity and the coefficient of soil erosion without changing the mechanical behavior. Lime and cement treatment induce a significant improvement of both internal erosion resistance and strength, and also keep the same level of hydraulic conductivity, and may even decrease it in some cases. The magnitude of these modifications is related to the nature and amount of the treatment product, and the curing period. The cross relationships between the hydraulic conductivity, the unconfined compression strength and the internal erosion were also assessed.
\end{abstract}

\section{INTRODUCTION}

\subsection{General context}

Erosion of earthen structure may be considered as one of the biggest issues faced by geotechnical engineers. The risk of failure of hydraulic structures (e.g. dams, levees, dikes, water retaining structure) may lead to catastrophic damages. As in 2005, the hurricane Katrina caused more than 100 billion dollars of economic loss (Briaud et al. 2008). FRY et al. (2012) identified 44 failures by erosion between 2010 and 2012, including 8 large dam failures.

To reduce the failure risk, it is important to use soils with high resistance to erosion. However, such materials are not always available. The solution is to improve the characteristics of the local soil available within the area of the project. Increasing the erosion resistance of soils could be met with soil treatments. Indeed, soil treatment with clay, lime or cement is often used in geotechnical engineering to improve a specific soil characteristic to reach a design value regarding strength, hydraulic conductivity, etc.

We will focus first on the internal erosion phenomena and especially the characterization of the internal erosion of soil by the Hole Erosion Test apparatus. Then, after a brief review about the state of art of soil treatment, we will present some available results about the internal erosion of treated soils.

\subsection{Internal erosion}

In this work, we were interested on the internal erosion of soils by piping. Piping is one of the internal erosion mechanisms. It is characterized by the initiation of a regressive erosion of particles from downstream to the upstream of the structure, inducing a development of cracks on concentrated leaks within the structures until forming a continuous pipe. According to Fell et al. (2003) the process of internal erosion and piping can be divided into four phases: the initiation, the continuation, the progression of erosion to form a pipe, and finally the formation of a breach.

In order to quantify the internal erosion characteristics of the soil, Wan \& Fell $(2002,2004)$ developed the Hole Erosion Test (HET). The test consists on following the growth of an existent hole in the soil sample. The HET gives the empirical erosion law of the soil that can be expressed as follows:

$\dot{\varepsilon}=k_{e r}\left(\tau-\tau_{c}\right)$

where $\dot{\varepsilon}=$ the rate of erosion per unit surface area of the hole per time $t\left(\mathrm{~kg} / \mathrm{m}^{2} / \mathrm{s}\right) ; \tau=$ the hydraulic shear stress along the hole $(\mathrm{Pa}) ; k_{e r}=$ the coefficient of soil erosion $(\mathrm{s} / \mathrm{m}) ; \tau_{c}=$ the critical shear stress $(\mathrm{Pa})$.

The parameters characterizing the soil erosion are then: $i)$ the critical shear stress $\left(\tau_{c}\right)$, corresponding to the minimum shear stress necessary to initiate the detachment of soil particles, and ii) the coefficient of 
soil erosion $\left(k_{e r}\right)$ which expresses the rate of erosion once it has been initiated.

To classify the soils by their resistance of internal erosion, Wan \& Fell (2002) proposed a classification based on $k_{e r}$. The erosion rate index $(I)$ is calculated $\left[I=-\log \left(k_{e r}\right)\right]$ and the soils are classified into 6 group of erodibility, from 1 (extremely rapid erosion) to 6 (extremely slow erosion).

To determine the internal erosion resistance of a specific soil, it is necessary to use a device capable of applying the necessary inlet pressure, and hence the necessary pressure drop across the soil sample needed to initiate the erosion of the studied soil. In the last decade, several optimizations were made since the first HET allowing more control of the hydraulic parameters, such as the hydraulic pressure drop across the sample or the water flow (Pham 2008, Indraratna et al. 2009, Whal 2010, Benahmed \& Bonelli 2012, Luthi et al. 2012, Haghighi et al. 2013).

The HET was used by several authors to study the factors which may affect the soil erodibility (e.g., initial water content, initial dry density and compaction energy). Wan \& Fell (2002), Lim (2006), and Attom (2012) showed that at the same initial dry density, soils exhibit a higher $I$ if they are compacted on the wet side of the optimum. The increase of initial dry density of soil induces a higher $I$ (Wan \& Fell 2002, Lim 2006) and also a higher $\tau_{c}$ (Benahmed \& Bonelli, 2012). Wahl (2010) showed that along the compaction curve, the highest $I$ values are obtained for the optimum initial water content.

\subsection{Soil treatments}

Several studies showed the enhancement of mechanical characteristics of soil after cement treatment (e.g. Al-Amoudi 2002, Bahar et al. 2004, Sariosseiri \& Muhunthan 2008). Other authors (e.g. Eades \& Grim 1966, Bell 1996, Rao \& Shivananda 2005) showed that lime treatment improves mainly the soil workability as well as the soil strength. Strength is generally lowered by the addition of a significant proportion of clay in a soil. However, addition of clay allows the reduction of the hydraulic conductivity of soils to reach a target value. The reduction amplitude of the hydraulic conductivity depends on the percentage and the nature of the clayey soil employed (e.g., Sivapullaiah et al. 2000, Chapuis et al. 2002, Mishra et al. 2011). The impact of lime and cement on hydraulic conductivity is less known. Bellezza \& Fratalocchi (2005) showed that the variation of the hydraulic conductivity after cement treatment is related, on the one hand, to the change in the distribution of grain size of the soil and, on the other hand, to the formation of cementitious compounds over time. Lime can be associated to an increase or a decrease of the hydraulic conductivity of a soil depending on the compaction conditions
(McCallister \& Petry 1991, Le Runigo et al. 2009, Cuisinier et al. 2011). In addition of the compaction conditions, the variation of hydraulic conductivity due to the addition of lime depends on the nature of treated soil and the amount of lime (e.g., El Rawi \& Awad 1981, McCallister \& Petry 1991).

Several authors studied the impact of clay treatment on the evolution of the erosion characteristics. Bennabi et al. (2012), Benahmed \& Bonelli (2012) and Haghighi et al. (2013) showed that increasing the clay percentage induces a higher $\tau_{c}$ and a lower $k_{e r}$. However, very limited number of studies dealt with the impact of lime and cement treatment on the erosion characteristics of soil. In past few years, some authors (e.g., Chevalier et al. 2012, Herrier et al. 2015) focused on the impact of lime on erosion characteristics of soils. Herrier et al. (2015) found that the treatment of $2 \%$ of lime allows an increase of $\tau_{c}$ and a decrease of $k_{e r}$ for a clayey silt depending on the curing time. The results of the study conducted by Indraratna et al. (2009) showed that: with $3 \%$ of cement the $\tau_{c}$ of a silty soil increased from 0 to 50 $\mathrm{Pa}$ and $k_{e r}$ decreased by two orders of magnitude. Also, Indraratna et al. (2009) found that the improving of the erosion characteristics is proportional to the amount of cement. This lack of studies dealing with lime and cement treatment is mainly related to technical limitations of the existing HET devices, which does not allow the application of the necessary range of the hydraulic shear stress needed to initiate the erosion of treated soils by lime and cement.

The available studies showed that treatment with clays, lime or cement could be beneficial for the soil erodibility. Nevertheless, the limited number of data did not provide enough information about the impact of clay treatment for silty soils or about lime and cement treatment regarding the combined role of curing time and percentage of treatment products.

\subsection{Objectives of the current study}

The main focus of the study is to depict the cross relationships between hydraulic conductivity, strength and erosion characteristics of treated soil. A special emphasis was put on internal erosion. A new enhanced Hole Erosion Test was developed especially to study the internal erosion of treated soils under high hydraulic shear stresses (Mehenni et al. 2016), and a general modified theoretical model was also suggested. The global effects of treatment products are then discussed in the case of the studied soil.

\section{MATERIALS AND METHODS}

\subsection{Materials characteristics}

The studied soil was a silty soil $\left[w_{L}=28.5 \%\right.$; $w_{P}=20.5 \%$; percentage of $\left.(<80 \mu \mathrm{m})=99.2 \%\right]$. This soil was extracted from the Northern part of 
France and it is intended to a future large scale use to build earth structure in permanent contact with water. Four types of treatment products were considered since they are often used in the field: kaolinite $(2,5$ and $9 \%)$, sodium-activated bentonite $(2,5$ and $9 \%$ ), quicklime ( 1 and $3 \%$ ) and cement CEM II (3 and $6 \%$ ). These amounts refer to the quantity of product calculated on a dry weight of the soil.

\subsection{Samples preparation}

The compaction behavior of each treated soil was determined (ASTM-D 698-98). For the specimen preparation, the water content of the soil was adjusted to the desired water content of compaction. After a storage period of 24 hours to homogenize the moisture content, the soil and the treatment product were mixed thoroughly. In the case of lime treatment, the mixture was left one hour in an airtight container before compaction. In the case of cement treatment compaction was carried out in the next few minutes (maximum 30 minutes) after treatment, to meet the setting time of the cement. For treatment by clay products, no specific time was needed between the mixing and the compaction. Then, the mixture was statically compacted, using a specific mold for each test (see section 2.3).

Samples were compacted on the wet side of the optimum: $w=w_{\mathrm{OMC}+2.5 \%} / \rho_{d}=0.96 \rho_{\text {dmax }}$, depending on the nature and the percentage of each treatment (Tab. 1). Where $w$ is the moisture content (\%), wOMC is the optimum moisture content $(\%), \rho_{d}$ is the dry density $\left(\mathrm{Mg} / \mathrm{m}^{3}\right)$ and $\rho_{\text {dmax }}$ is the maximum dry density $\left(\mathrm{Mg} / \mathrm{m}^{3}\right)$.

In case of lime and cement treatment different curing periods were tested $(0,7,30$ and 90 days). During the curing period, the compacted specimens were wrapped in plastic sheets and kept at $20.0 \pm$ $1.5^{\circ} \mathrm{C}$ to prevent any water loss.

Table 1. Compaction characteristics of treated silt.

\begin{tabular}{llll}
\hline $\begin{array}{l}\text { Nature of } \\
\text { treatment }\end{array}$ & Notation & $\begin{array}{l}\text { Dry density } \\
\rho_{d}\left(\mathrm{Mg} / \mathrm{m}^{3}\right)\end{array}$ & $\begin{array}{l}\text { Moisture } \\
\text { content } w(\%)\end{array}$ \\
\hline Untreated silt & S & 1.73 & 17.5 \\
$+1 \%$ lime & SL 1\% & 1.70 & 20.0 \\
$+3 \%$ lime & SL 3\% & 1.68 & 20.0 \\
$+3 \%$ cement & SC 3\% & 1.75 & 17.5 \\
$+6 \%$ cement & SC 6\% & 1.75 & 17.5 \\
$+2 \%$ bentonite & SB 2\% & 1.74 & 17.8 \\
$+5 \%$ bentonite & SB 5\% & 1.74 & 18.8 \\
$+9 \%$ bentonite & SB 9\% & 1.68 & 20.0 \\
$+2 \%$ kaolinite & SK 2\% & 1.73 & 18.0 \\
$+5 \%$ kaolinite & SK 5\% & 1.75 & 17.5 \\
$+9 \%$ kaolinite & SK 9\% & 1.74 & 18.3 \\
\hline
\end{tabular}

\subsection{Testing program}

To determine the global effect of soil treatment, the study was focused on three characteristics: i) the unconfined compression strength (UCS) (ASTM-D D 2166). The tests were carried out with a constant rate of displacement of $1.05 \mathrm{~mm} / \mathrm{min}$, and the specimen size was $70 \times 35 \mathrm{~mm}$.

ii) the saturated hydraulic conductivity $(k)$ (ASTM-D 5084), a flexible wall permeameter (triaxial cells) and a pressure-volume controller were used. The specimen size was $70 \times 35 \mathrm{~mm}$.

iii) the internal erosion by the HET. A new enhanced HET was developed specially to study the internal erosion of treated soils under high hydraulic shear stress (Mehenni et al. 2016). The device, the procedures and the theoretical model are briefly presented in the next section.

\section{THE ENHANCED HET}

In this part, details are given about the principle of the test, the device, the test procedure and the suggested theoretical model used to assess the erosion characteristics of treated soils.

\subsection{The HET principle and device}

The principle of the HET is to establish a water flow though a cylindrical hole preformed initially in a soil specimen. The water flow produced hydraulic shear stresses at the soil/water interface. These hydraulic shear stresses induced the erosion of soil by the progressive detachment of soil particles. The main objective is to determine the growth of the hole during the erosion by monitoring several parameters during the test: $i)$ the water flow passing through the hole, ii) the pressure drop between the upstream and the downstream of the soil specimen and iii) the turbidity signal of the effluents.

We recently developed an optimized HET (Fig. 1) to measure the internal erosion of compacted treated soils (Mehenni et al. 2016). This device included several enhancements allowing the application of a high level of the inlet pressure, which induced high level of the pressure drop across the sample and hence high level of hydraulic shear stress along the hole.

The main enhancement was made on the applying pressure system. We used a special air-water reservoir to apply a constant pressure, the maximum applied pressure being more than $670 \mathrm{kPa}$, which will induce a pressure drop of $670 \mathrm{kPa}$ between upstream and downstream of soil specimen. As an example, if we apply an initial inlet pressure of $650 \mathrm{kPa}$ to a sample with an initial hole radius $r=1.5 \mathrm{~mm}$ and a length $L=70 \mathrm{~mm}$, then the initial applied pressure can reach more than $7000 \mathrm{~Pa}$ (see equation 3 ).

Some enhancements were made also on the configuration of the testing cell where the soil sample is strongly held to the chambers from both sides. This prevented any loss of pressure and water leakage. 
This enhanced configuration allowed better holding of soil specimen during the test even under high level of pressure drop.

The water flow was measured with an ultrasonic flowmeter placed at the entrance of the testing cell. A turbidimeter was connected to the exit of the test cell allowing the measurement of the effluents turbidity.

\subsection{Test procedures}

After the curing period, the initial hole (between 3 and $6 \mathrm{~mm}$ ) was made by drilling in the specimen center, and then the specimen was placed in the testing cell. The system is filled with water to ensure that no air bubbles are blocked inside the testing cell or the pipes. This step was made under a low flow while the vent valves are open.

The tests were run by the application of a constant pressure at the inlet of the sample. Preliminary tests were performed, for each treatment, to define the range of the applying pressure necessary to initiate the erosion by the detachment of soil particles. The necessary range of the applied pressure is related to the nature of the soil and to the treatment product.

Applying the necessary inlet pressure leads to initiate the process of erosion of the hole. At the beginning of the test, the erosion process started by fast detachment of soils particles due to the high level of the pressure drop between the inlet and the outlet of the sample. The progressive detachment of soil particles induces the growth of the hole diameter, this causes: $i$ ) an increase of the flow through the specimen hole and ii) a decrease of the drop pressure between the inlet and the outlet of the sample. This lowering of the pressure drop causes a drop of the applied hydraulic shear stresses, and hence less detachment of soil particles. The decrease of rate of erosion continues until a complete ending of erosion process where no further detachment of soils parti- cles occurred.

At the end of the test, the testing cell is dismantled, and the hole in the specimen is filled with liquid wax to determine the final shape of the eroded hole.

\subsection{The theoretical model}

To establish the erosion law it is necessary to determine both the erosion rate and the applied hydraulic shear stress during the whole erosion progressions. The main assumptions are related to the shape of the hole during the erosion process, which is assumed to remain circular.

The erosion rate $\dot{\varepsilon}$ for a given hydraulic shear stress can be expressed by the eroded soil mass per unit surface area of the hole per time $t$. For a circular hole:

$\dot{\varepsilon}=\rho_{d} \cdot d r(t) / d t$

where $d r(t)=$ variation of the radius $r$ at the elementary time $d t$.

The applied shear stress $\tau$ is related to the hydraulic gradient $\triangle P$ between the inlet and the outlet of the hole. $\tau$ is calculated using the principle of the equilibrium forces carried out on a volume of fluid between the inlet and outlet of the hole. For a circular hole:

$\tau_{c}=\Delta P /(2 . L . r(t))$

where $r(t)=$ the radius at the elementary time $d t$.

Equations 2 and 3 show that the determination of the erosion law calls for the determination of the radius of the hole during the whole erosion process.

The turbidity signal was used to determine $r(t)$ (Reddi et al. 2000, Pham 2008, Muttuvel, 2008, Benahmed \& Bonelli 2007, Haghighi 2012). This method consists in the calibration of the relationship between the turbidity signal and the soil particles concentration for the different treated soils speci-

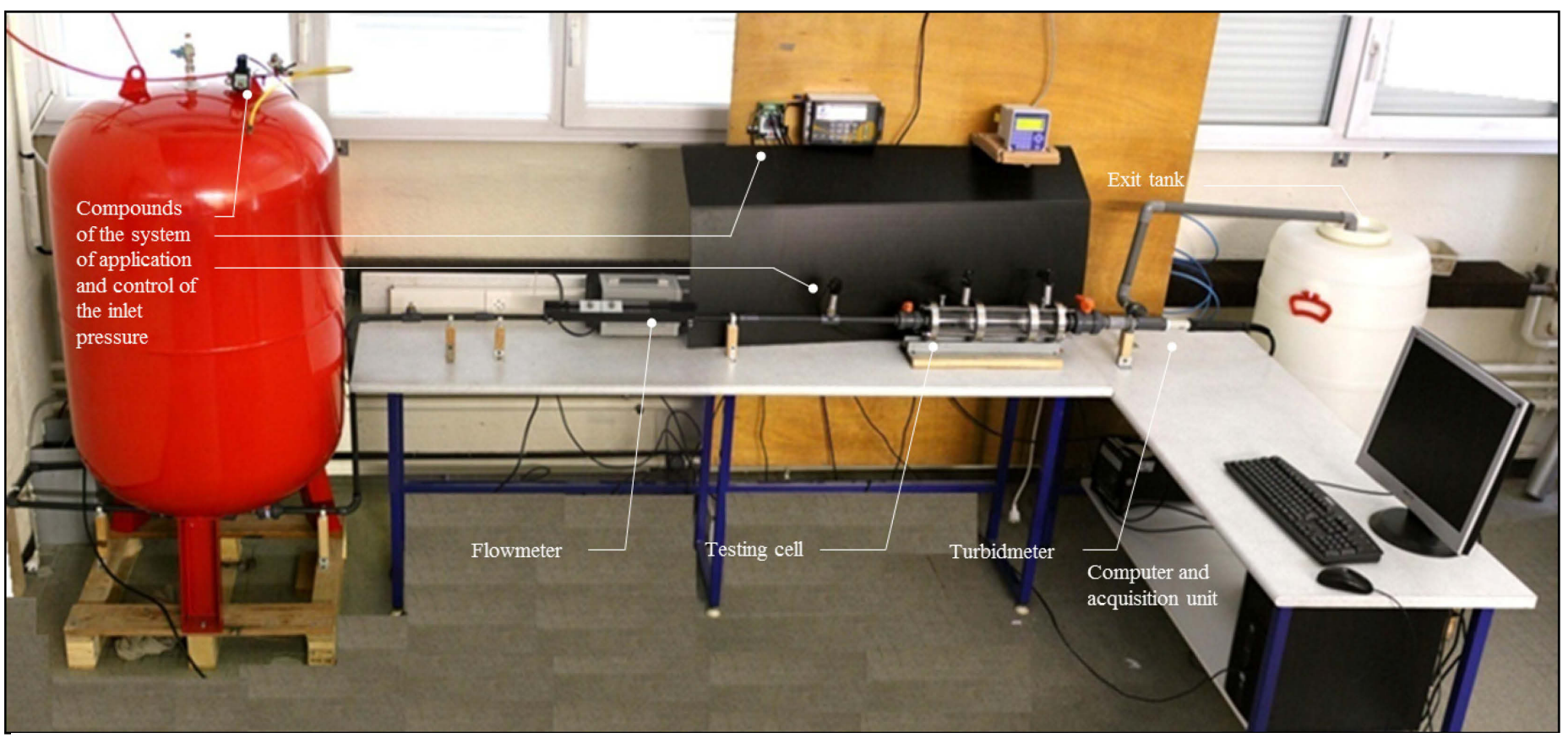

Figure 1. The new enhanced Hole Erosion Test designed to conduct tests on treated soil under high hydraulic shear stresses 
mens. Then, during the test, the concentration of the soils particles in the effluents is measured for each time $t$. The radius $r(t)$ can be calculated with the assumption that the eroded soil is uniform along the hole.

\subsection{Validation of the new enhanced HET}

\subsubsection{Repeatability of the tests}

To evaluate accuracy of the device, we conducted several repeatability tests using the untreated soil. Only specimens with uniform cross section along the eroded hole were kept for the study in order to respect the assumption of the theoretical model. Results are given in Table 2. The device ensures good repeatability and the ratios of the variation of the two characteristics are quite the same as the ratios usually obtained when conducting the HET (e.g. Wan \& Fell 2002, Haghighi 2012).

Table 2. Repeatability tests on the untreated soil.

\begin{tabular}{lll}
\hline Test $\mathrm{n}^{\circ}$ & $\begin{array}{l}\text { Coefficient of soil } \\
\text { erosion } k_{e r}(\mathrm{~s} / \mathrm{m})\end{array}$ & $\begin{array}{l}\text { Critical shear } \\
\text { stress } \tau_{c}(\mathrm{~Pa})\end{array}$ \\
\hline 1 & $2.58 \times 10^{-04}$ & 391 \\
2 & $2.16 \times 10^{-04}$ & 389 \\
3 & $2.22 \times 10^{-04}$ & 398 \\
4 & $1.13 \times 10^{-04}$ & 491 \\
5 & $3.04 \times 10^{-04}$ & 615 \\
6 & $1.30 \times 10^{-04}$ & 291 \\
\hline
\end{tabular}

3.4.2 Sensitivity of the erosion law to the hole shape The theoretical model was based on a circular shape of the eroded hole. However, in some cases, the eroded cross section can be slightly different from a circular shape, and may be more approached by an ellipsoid. We conducted a comparative study to evaluate the sensitivity of the calculated characteristics to the shape of the hole. For this purposes, we developed a general calculation model based on an ellipsoidal shape. $\dot{\varepsilon}$ and $\tau$ are then calculated then using equations 4 and 5 .

$\dot{\varepsilon}=\rho_{d} \cdot \sqrt{\frac{2 \alpha^{2}}{\left(\alpha^{2}+1\right)}} \cdot b(t)$

$\tau=\frac{\Delta P(t)}{L} \cdot \frac{\alpha}{\sqrt{2\left(\alpha^{2}+1\right)}} \cdot b(t)$

where $b(t)=$ variation of the small radius $b$ of the ellipsoid at the elementary time $d t ; \alpha=$ ratio between the radii of the ellipsoid ( $\alpha=1$ for circular shape). $\alpha$ is measured at the end of the test and assumed to remain constant during the whole test.

The comparative study was made using, on one side, the classic method with only circular shape and, on the other side, the general suggested method using the real shape approached by an ellipsoid. The analysis was conducted for the same sets of HET raw results ( 2 examples are presented in Table 3 ).

The results showed that a slight variation of the hole cross section from the circular shape did not affect significantly the erosion characteristics. However, a significant variation of the cross section shape of the hole may lead to an inaccurate estimation of the critical shear stress and the coefficient of soil erosion. Hence, the use of the suggested general theoretical model allows a better assessment of the erosion characteristic of the tested soils. More details are provided in Mehenni (2015) and Mehenni et al. (2016).

Table 3. Sensitivity of the erosion characteristics to the cross section shape of the hole.

\begin{tabular}{ll}
\hline Example 1 & \\
Circular shape $(\alpha=1.00)$ & Ellipsoidal shape $(\alpha=1.31)$ \\
$k_{e r}=2.57 \times 10^{-04} \mathrm{~s} / \mathrm{m}$ & $k_{e r}=2.22 \times 10^{-04} \mathrm{~s} / \mathrm{m}$ \\
$\tau_{c}=389 \mathrm{~Pa}$ & $\tau_{c}=398 \mathrm{~Pa}$ \\
\hline Example 2 & \\
Circular shape $(\alpha=1.00)$ & Ellipsoidal shape $(\alpha=1.91)$ \\
$k_{e r}=8.85 \times 10^{-05} \mathrm{~s} / \mathrm{m}$ & $k_{e r}=5.05 \times 10^{-05} \mathrm{~s} / \mathrm{m}$ \\
$\tau_{c}=640 \mathrm{~Pa}$ & $\tau_{c}=519 \mathrm{~Pa}$ \\
\hline
\end{tabular}

\subsubsection{Validation of the radius calculation method}

To evaluate the accuracy of the suggested general theoretical model, we compared the final eroded diameter measured at the end of the test with the diameter calculated using the turbidity signal and taking into account the coefficient $\alpha$ relating the two diameters of the ellipsoid.

Some examples of comparison are given in Figure 2. The results confirm the relevance of the used technique to determine the hole diameter during the test using the soil particles departure.

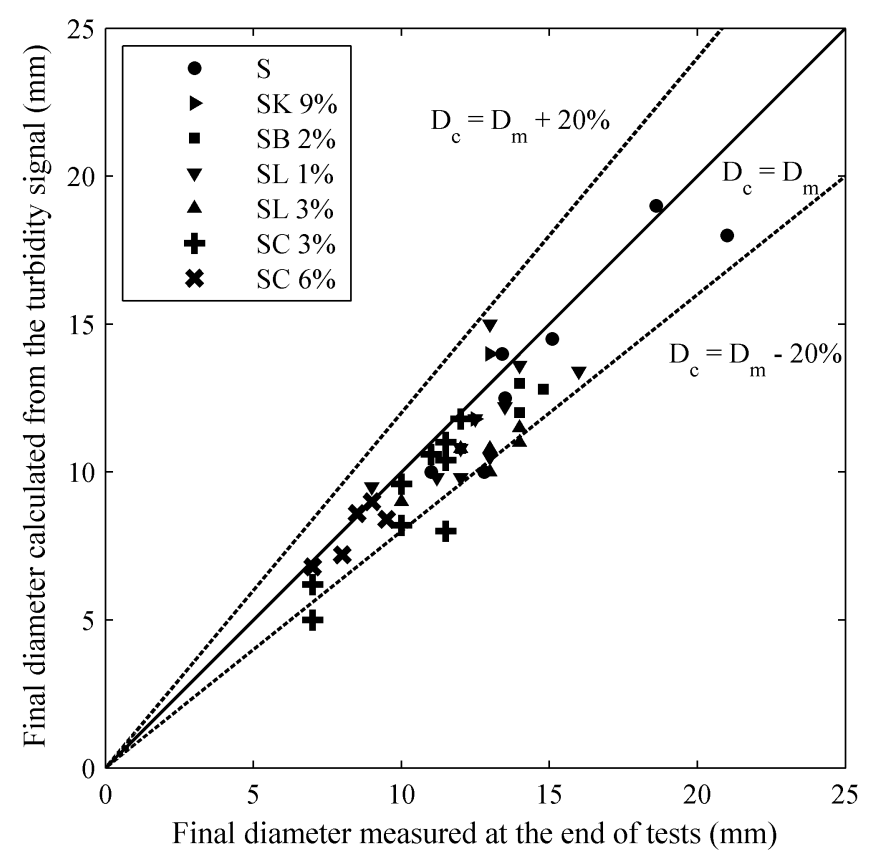

Figure 2. Comparison between the calculated diameter and the measured diameter at the end of the tests. 


\subsubsection{Impact of the drilling process}

The initial hole in the specimen was made by drilling. However the drilling process induced a mechanical action which could disturb the soil surface especially in the case of the brittle materials (case of lime and cement treated soils). We conducted a comparative study on the impact of the time where occurs the hole drilling (before or after different curing time) for lime and cement treated silt. The results showed that after curing time, the drilling process disturbed a significant area near to the drilled hole. This part of the specimen eroded more easily (meaning at lower critical shear stress) than the undisturbed part of the soil specimen. This results had lead to take into account this behavior during the analysis of the erosion process and the treatment of the HET data.

\section{HYDRO-MECHANICAL BEHAVIOR}

In this part, the impact of each treatment on $k$ and $U C S$ is given and the main results are briefly discussed.

\subsection{Untreated silt}

For the untreated silt compacted at the wet side of the optimum $\left(w=17.5 \% / \rho_{\mathrm{d}}=1.73 \mathrm{Mg} / \mathrm{m}^{3}\right)$ the $U C S$ was $142 \mathrm{kPa}$. This value was considered as the reference value for the study of the treatment impact on the mechanical behavior. The $k$ of the untreated silt was $6.0 \times 10^{-09} \mathrm{~m} / \mathrm{s}$. This low level of the hydraulic conductivity can be related, in one hand, to the high percentage of the fine particle fraction less than $80 \mu \mathrm{m}(99.2 \%)$ and, on the other hand, to the compaction conditions (e.g. Mitchell et al. 1965, Boynton \& Daniel 1985). In fact, compaction in the wet side of the optimum allows a dense rearrangement of soil particles and reduces the porosity, hence the circulation paths of the water flow are reduced and the hydraulic conductivity is lower. This value of the $k$ is considered as the reference for the study of the treatment impact on the hydraulic behavior.

Table 4. Impact of treatment in the $k$ of the silt.

\begin{tabular}{ll}
\hline Nature of treatment & $k(\mathrm{~m} / \mathrm{s})$ \\
\hline Untreated silt & $6.0 \times 10^{-09}$ \\
$+2 \%$ kaolinite & $2.3 \times 10^{-09}$ \\
$+5 \%$ kaolinite & $1.3 \times 10^{-09}$ \\
$+9 \%$ kaolinite & $7.3 \times 10^{-10}$ \\
$+2 \%$ bentonite & $2.2 \times 10^{-10}$ \\
$+5 \%$ bentonite & $5.1 \times 10^{-11}$ \\
$+9 \%$ bentonite & $2.6 \times 10^{-11}$ \\
$+1 \%$ lime $(90$ days $)$ & $9.0 \times 10^{-09}$ \\
$+3 \%$ lime $(90$ days $)$ & $9.7 \times 10^{-10}$ \\
$+3 \%$ cement $(90$ days $)$ & $1.9 \times 10^{-09}$ \\
$+6 \%$ cement $(90$ days $)$ & $7.3 \times 10^{-10}$ \\
\hline
\end{tabular}

\subsection{Clay treatment}

Specimens treated with kaolinite and bentonite exhibit no significant changes of the UCS. For all samples compacted on the wet side of the optimum the mean value varied between 142 and $186 \mathrm{kPa}$.

The addition of 2 and $5 \%$ of kaolinite reduced $k$ values down to $2.3 \times 10^{-09} \mathrm{~m} / \mathrm{s}$ and $1.3 \times 10^{-09} \mathrm{~m} / \mathrm{s}$ respectively. The use of a higher amount of kaolinite $(9 \%)$ resulted in a greater reduction of $k$ which reached $7.3 \times 10^{-10} \mathrm{~m} / \mathrm{s}$. The addition of bentonite lead to a significant reduction of $k$ of the silt. The values of $k$ were $2.2 \times 10^{-10} \mathrm{~m} / \mathrm{s}, 5.1 \times 10^{-11} \mathrm{~m} / \mathrm{s}$ and $2.6 \times 10^{-11} \mathrm{~m} / \mathrm{s}$ for 2,5 and $9 \%$ of bentonite content respectively (Tab. 4).

\subsection{Lime treatment}

Figure 3 shows the impact of curing period on the $U C S$ of lime treated specimens. Without curing time, the $U C S$ was 200 and $250 \mathrm{kPa}$ for 1 and $3 \%$ of lime respectively. After 90 days of curing period the UCS reached values around $300 \mathrm{kPa}$ for $1 \%$ of lime and values around $500 \mathrm{kPa}$ for $3 \%$ of lime. Compared to the untreated soil, the UCS increased by a ratio of 2 and 3.5 , for 1 and $3 \%$ of lime respectively.

The $k$ was not significantly modified by the addition of $1 \%$ of lime, and was slightly reduced by the addition of $3 \%$ of lime treatment (Tab. 4). The $k$ of the lime treated silt remained mostly at the same order of magnitude regarding the curing period. These results showed that the compaction on the wet side of the optimum allows to maintain the same level of $k$ as for the soil before treatment besides the fact that the dry density was lower $\left(1.70\right.$ and $1.68 \mathrm{Mg} / \mathrm{m}^{3}$ for 1 and $3 \%$ of lime respectively).

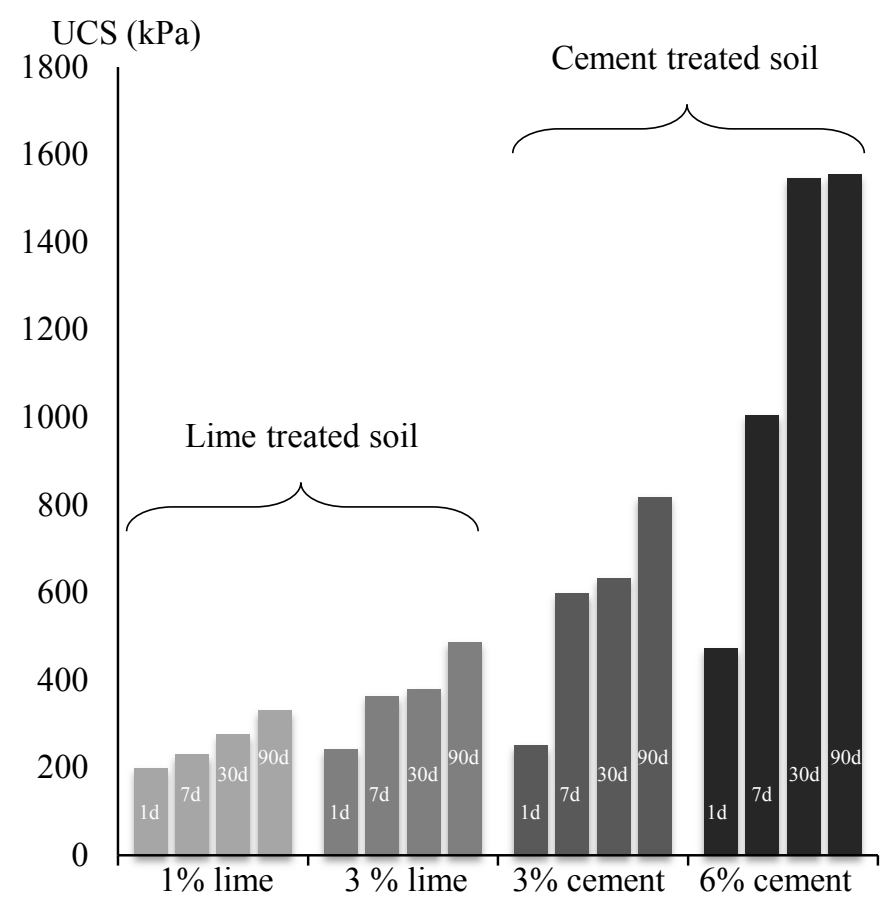

Figure 3. Impact of lime and cement treatment on the UCS of the studied silt. 


\subsection{Cement treatment}

As expected the UCS of cement treated silt increased with the curing period (Fig. 3). At 90 days of curing period the $U C S$ is about $800 \mathrm{kPa}$ for $3 \%$ of cement, and around $1500 \mathrm{kPa}$ for $6 \%$ of cement. Compared to the untreated soil, the UCS increases by a ratio of 4.5 and 5 , for 3 and $6 \%$ of cement respectively. This results were obtained for specimens compacted in a wet side of their specific optimum.

After cement treatment, the $k$ value decreased, slightly with $3 \%$ of cement, and with one order of magnitude with $6 \%$ of cement (Tab. 4).

\section{INTERNAL EROSION}

To study the erosion of the treated silt it was necessary to apply a required inlet pressure, hence hydraulic shear stress, to initiate the erosion of the tested specimen. The required inlet pressure depends on the treatment products and amounts. While, silt treated with clay products required an inlet pressure varying between 80 to $120 \mathrm{kPa}$, lime and cement treated specimens required a higher range of inlet pressure up to $650 \mathrm{kPa}$ for $6 \%$ of cement.

\subsection{Untreated silt}

HET results conducted on the untreated silt (Tab. 2) showed that $k_{e r}$ varies between $1.13 \times 10^{-04}$ and $3.04 \times 10^{-04} \mathrm{~s} / \mathrm{m}$ and $\tau_{c}$ varies between 291 and $615 \mathrm{~Pa}$. The mean values for the untreated silt are: $k_{e r}$ $=2.0 \times 10^{-04} \mathrm{~s} / \mathrm{m}$ and $\tau_{c}=429 \mathrm{~Pa}$, and $I$ varies between 3.59 and 3.95. Thereby all untreated specimens are classified in "moderately rapid" group. For the next part, the impact of treatment will be addressed for both $k_{e r}$ and $\tau_{c}$ as presented in Figure 4.

\subsection{Clay treatment}

The use of $2 \%$ of kaolinite did not change $k_{e r}$, the mean value remained the same as the untreated silt, however $\tau_{c}$ tend to slightly increase with a mean value of $607 \mathrm{~Pa}$. The use of $9 \%$ of kaolinite decreased $k_{e r}$ by one order of magnitude with a mean value of $6.92 \times 10^{-05} \mathrm{~s} / \mathrm{m}$, and induced a slight increase of $\tau_{c}$ with a mean value of $513 \mathrm{~Pa}$. According to the classification of Wan \& Fell (2002), silt specimens treated with $2 \%$ of kaolinite are classified in "moderately rapid" group, and silt specimens treated with $9 \%$ of kaolinite are classified in "moderately slow" group. Therefore, $9 \%$ of kaolinite was required to significantly modify soil erodibility (Fig. 4).

Treatment with 2 and $9 \%$ of bentonite leads to a decrease of $k_{e r}$ by one order of magnitude (Fig. 4). $\tau_{c}$ decreased slightly but the values are included in the interval of variation of $\tau_{c}$ of the untreated silt. The silt treated with bentonite is classified in "moderately slow" group for both used amounts.

\subsection{Lime treatment}

For treatment with $1 \%$ of lime, $k_{e r}$ varied between $1.09 \times 10^{-04} \mathrm{~s} / \mathrm{m}$ and $2.87 \times 10^{-04} \mathrm{~s} / \mathrm{m}$ regardless the curing time, and $\tau_{c}$ increased with a value varying between 963 and 1538 after 30 days of curing period. For treatment with $3 \%$ of lime $k_{e r}$ varied between $1.54 \times 10^{-04} \mathrm{~s} / \mathrm{m}$ and $4.52 \times 10^{-04} \mathrm{~s} / \mathrm{m}$ regardless the curing time, and $\tau_{c}$ increased with a value varying between 1035 and $1845 \mathrm{~Pa}$ after 30 days of curing period. All results of the HET conducted on lime treated silt are given in Figure 4.

The curing time seems to have no effect on $k_{e r}$. However, $\tau_{c}$ tends to slightly increase with the curing time. $k_{e r}$ did not change even if the links between the soil particles are assumed to be stronger than the un-
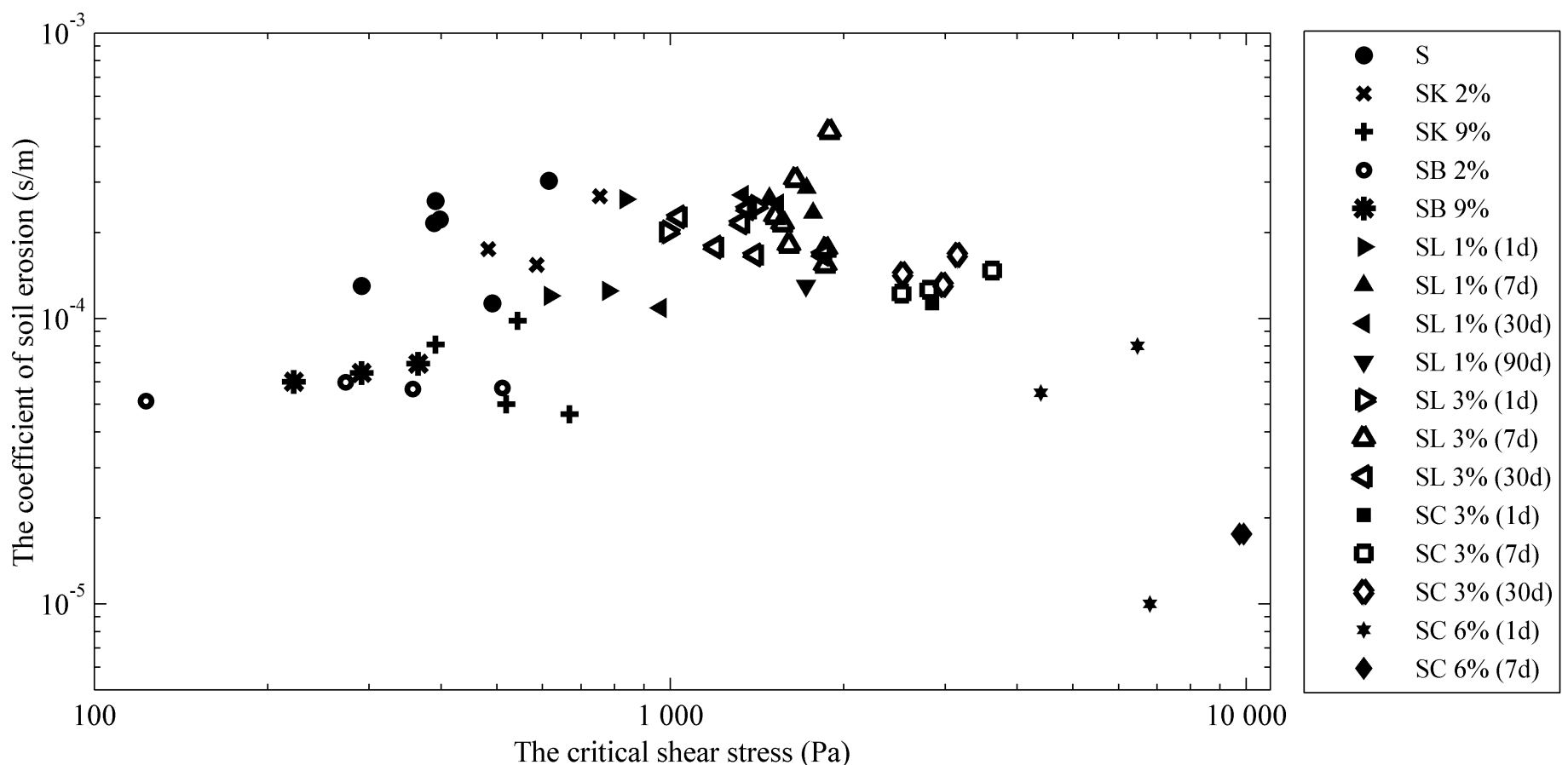

The critical shear stress $(\mathrm{Pa})$

Figure 4. Impact of treatment in the internal erosion characteristics of the studied silt. 
treated soil. This can be related to the detachment process of soil particles. Indeed, we observed during the erosion of lime treated silt that the detachment of soil comes often by a detachment of the entire aggregate of soil and not particle by particle. This means that the erosive forces break firstly the weaker bonds between aggregates.

All the specimens of lime treated silt are classified in "moderately rapid" group as well as the untreated soil, regardless the lime percentage or the curing time. The impact of lime treatment does not appear in this case for the only reason that the classification of Wan \& Fell (2002) does not take into consideration the critical shear stress.

\subsection{Cement treatment}

In the case of treatment with $3 \%$ of cement $k_{e r}$ varied between $1.13 \times 10^{-04} \mathrm{~s} / \mathrm{m}$ and $1.67 \times 10^{-04} \mathrm{~s} / \mathrm{m}$, regardless the curing period. Furthermore, $\tau_{c}$ varied between 2520 and $3619 \mathrm{~Pa}$ with a mean value around $2900 \mathrm{~Pa}$. The curing time seems to have no effect on the evolution of both characteristics (Fig. $4)$. For treatment with $6 \%$ of lime $k_{e r}$ varied between $1.00 \times 10^{-05} \mathrm{~s} / \mathrm{m}$ and $8.00 \times 10^{-05} \mathrm{~s} / \mathrm{m}$, which is one order of magnitude less than the untreated silt. $\tau_{c}$ varied between 4400 and $6800 \mathrm{~Pa}$ for a curing time of 1 day, and reached a mean value of 9814 after 7 days of curing period.

For $3 \%$ of cement the improvement comes at early ages and no further significant modification was observed. While for a higher amount of cement, an increase occurred with the curing time. This is related to the hardness of cement which may take more time for higher percentage.

Cement treated silt is classified in "moderately rapid" group for $3 \%$ of cement, and in "moderately slow" group for $6 \%$ of cement.

\section{RELATIONSHIPS BETWEEN THE HYDRO- MECHANICAL CHARACTERISTICS AND THE INTERNAL EROSION CHARACTERISTICS}

Figure 5 depicts the variation of the critical shear stress $\left(\tau_{c}\right)$ as a function of the unconfined compression strength (UCS) for treated and untreated silt specimens. The maximum values of $\tau_{c}$ are reached for the maximum values of the UCS, and also the increase of the UCS induces an increase of the $\tau_{c}$. The results show that the relationship between $U C S$ and $\tau_{c}$ can be defined by three ranges as given in Table 2 . These ranges of variation can be used for a similar silty soil as a preliminary evaluation tool of the critical shear prior to the conduction the HET.

Figure 6 gives the evolution of the coefficient of soil erosion $\left(k_{e r}\right)$ as a function of the hydraulic conductivity $(k)$. The smaller values of $k_{e r}$ are obtained for the lower values of the hydraulic conductivity, and all specimens with $k$ lower than $10^{-10} \mathrm{~m} / \mathrm{s}$ exhibits $k_{e r}$ less that $10^{-4} \mathrm{~s} / \mathrm{m}$. Although, no direct relationship can be drawn between the $k_{e r}$ and $k$, it seems that the more $k$ is low, the more $k_{e r}$ is small.

Table 5. Relationship between the critical shear stress and the unconfined compression strength.

\begin{tabular}{ll}
\hline Unconfined compression strength & Critical shear stress \\
$U C S(\mathrm{kPa})$ & $\tau_{c}(\mathrm{~Pa})$ \\
\hline $0-500$ & $0-2000$ \\
$500-1000$ & $2000-4000$ \\
$>1000$ & $>4000$ \\
\hline
\end{tabular}

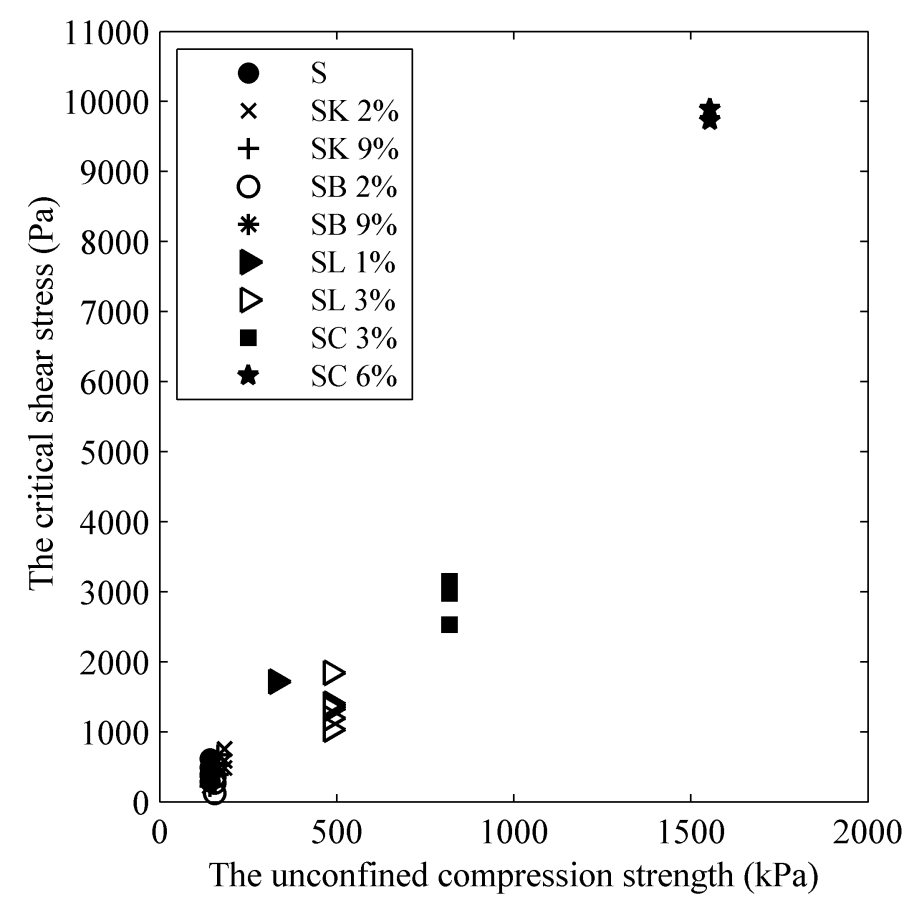

Figure 5. Relationship between the critical shear stress and the unconfined compression strength for the studied silt.

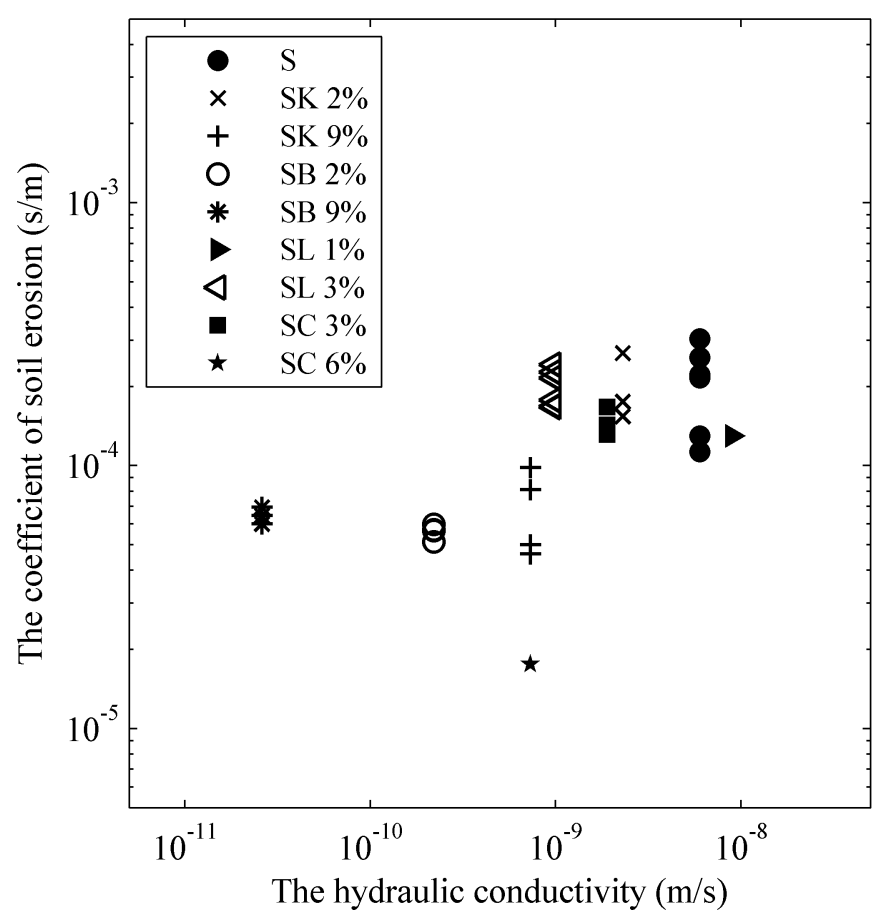

Figure 6. Relationship between the coefficient of soil erosion and the hydraulic conductivity for the studied silt. 


\section{DISCUSSION}

The main objective of this work was to determine the global effect of soil treatment on the hydromechanical characteristics and the internal erosion, and also the relationship between these characteristics. We selected a unique compaction state on the wet side of the compaction curve specific to each treatment. This state was chosen to meet the minimum of hydraulic conductivity.

The clay treatment did not change significantly the range of $\tau_{c}$. This insensitivity of $\tau_{c}$ can be explained by the fact that the compaction states were practically the same for untreated and clay treated silt, and also by the fact that clay treatment did not change the mechanical behavior of the silt. The main impact of clay treatment on the internal erosion was the decrease of the coefficient of soil erosion. For kaolinite treatment, $k_{e r}$ was related to the percentage of the kaolinite. This can be explained by the fact that with high amount of kaolinite $(9 \%)$ the size distribution of the silt was changed. It is known that the percentage of clay fraction enhances the erosion resistance of sandy soils (e.g. Bennabi et al. 2012, Benahmed \& Bonelli 2012) this seems to be the same also in the case of silty soils.

Both for the internal erosion and the hydraulic conductivity, the nature of the clay particles seemed to have also an important effect. Indeed, the addition of only $2 \%$ of bentonite has similar effects to the addition of $9 \%$ of kaolinite. It is well known that the hydraulic conductivity is related to the mineralogical nature of the clay particle of soil (e.g. Mishra et al. 2011), we can assume that the enhancement of internal erosion by clay treatment is also related to the mineralogical nature of the clay particles of soil.

Lime treatment, as well as cement treatment, induced modifications within the structure of silt by creating new cementious compounds. This conferred to the soil a better strength. It appeared also that these treatments induced an increase of the erosion resistance reflected by a higher critical shear stress. For both hydro-mechanical characteristics and internal erosion, the enhancement was greater with cement than with lime. The enhancement was also more pronounced when using higher amount of lime and cement.

For lime treatment, it appeared that the curing period did not have a significant effect on the erosion characteristics or the hydraulic conductivity, and a slight increase of the mechanical strength. We can assume then that the enhancement by lime treatment is related firstly to the short term effect of lime, and secondly to the development of the pozzolanic reactions. While, for cement treatment, the effects of the curing time were related to the amount of cement. For a high percentage of cement $(6 \%)$ a better enhancement occurred with the curing period. Hence, we can assume that the cement enhacement is related to the development of the cementious compounds. Thereby, starting from a certain amount of cement, the evolution of internal erosion is similar to the evolution of to the mechanical behavior. These optimizations are mainly related to hardness of cement and the development of cementious compounds which induces strong bonds between soils particles. Hence the strength is increased and the detachment of soil particles becomes more difficult, conferring then to the soil better resistance to the erosion.

\section{CONCLUSION}

The main object of this study was to study the impact of soil treatment on the hydro-mechanical characteristics and the internal erosion of treated compacted silt. To quantify the erosion of the treated soils we developed an optimized HET and we suggest also a general theoretical model to analyze of the HET results. Based on the results mentioned above, the following conclusions can be made:

- The use of the clayey soil as a treatment product improves the hydraulic conductivity and reduces the rate of erosion of soil particles. The effect is more pronounced by the nature and the percentage of the clayey soil.

- Lime treatment can improve the mechanical behavior of soil as well as the internal erosion by increasing the critical shear stress. Besides, if the compaction condition are respected the hydraulic conductivity of the soil remain unchanged.

- Cement treatment improves the mechanical behavior, enhance the erosion resistance of soil and keep the hydraulic conductivity lower than the untreated soil.

This study showed the short term enhancements induced by clay, lime and cement treatment on several geotechnical characteristics, and especially on the internal erosion. Nevertheless, it is of paramount importance to conduct also a durability study of the long term behavior of treated soils in order to ensure the sustainability of the treatment effects.

\section{REFERENCES}

Al-Moudi, O.S.B. 2002. Characterization and chemical stabilization of Al-Qurayyah sabkha soil. Journal of Materials in Civil Engineering 14(6): 478-484.

ASTM-D 2166 - 98a 1998. Standard Test Method for Unconfined Compressive Strength of Cohesive Soil. American Society For Testing and Materials. 1-6.

ASTM-D 5084 - 90 1997. Standard Test Method for Measurement of Hydraulic Conductivity of Saturated Porous Materials Using a Flexible Wall Permeameter. American Society For Testing and Materials. 1-8.

ASTM-D 698-98 1998. Standard Test Method for Laboratory Compaction Characteristics of Soil Using Standard Effort. American Society For Testing and Materials. 1-8. 
Attom, M. 2012. The effect of compaction condition and initial water content on soil erosion. ICSE6: 49-56. Paris.

Bahar, R., Benazzoug, M. \& Kenai, S. 2004. Performance of compacted cement-stabilised soil. Cement and Concrete Composites, 26: 811-820.

Bell, F.G. 1996. Lime stabilization of clay minerals and soils. Engineering Geology 42: 223-237.

Bellezza, I. \& Fratalochi, E. 2006. Effectiveness of cement on hydraulic conductivity of compacted soil-cement mixtures. Ground Improvement 10(2): 77-90.

Benahmed, N. \& Bonelli, S. 2007. Etude expérimentale de l'érosion interne d'une kaolinite. 25éme rencontre de l'AUGC 2007: 1-8. Bordeaux, France.

Benahmed, N. \& Bonelli, S. 2012. Investigation concentrated leak erosion behaviour of cohesive soils by performing hole erosion tests. European Journal of Environmental and Civil Engineering. 16(1): 43-58.

Bennabi, A., Karoui, T., Benamar, A. \& Wang, H.Q. 2012. Some elements of comparison between two laboratory devices for soil erosion testing. ICSE6: 1089-1096. Paris.

Boynton, S. \& Daniel, D.E. 1985. Hydraulic conductivity tests on compacted clay. Journal of Geotechnical Engineering 111(4): 465-478.

Chapuis, R.P. 2002. The 2000 R.M. Hardy Lecture: Full-scale hydraulic performance of soil-bentonite and compacted clay liners. Canadian Geotechnical Journal 39: 417-439.

Briaud, J.-L., Levee Erosion by Overtopping in New Orleans during the Katrina Hurricane. Journal of geotechnical and geoenviromenal engineering 134(5): 618-632.

Chevalier, C., Haghighi, I. \& Herrier, G., 2012. Resistance to erosion of lime treated soils: a complete parametric study in laboratory. ICSE6: 1065-1072. Paris.

Cuisinier, O., Auriol, J.C., Le Borgne, T., Denelle, D., 2011. Microstructure and hydraulic conductivity of a compacted lime-treated soil. Engineering Geology 123(2): 187-193.

Eades, J.L. \& Grim, R.E. 1966. A quick test to determine lime requirements of lime stabilization. Highway Research Record 139: 61-72.

EL-Rawi, N. \& Awad, A.A.A. 1981. Permeability of lime stabilized soils. Transportation engineering journal 127: 25-35.

Fell, R., Wan, C.F., Cyganiewicz, J. \& Foster, M. 2003. Time for development of internal erosion and piping in embankment d ams. Journal of geotechnical and Geoenviromental engineering 129(4): 307-314.

Fry, J.J., Vogel, A., Royet, P. \& Courivaud, J.-R. 2012. Dam failures by erosion: lessons from ERINOH data bases. ICSE6: 49-56. Paris.

Haghighi, I., (2012). Caractérisation des phénomènes d'érosion et de dispersion des sols : développement d'essais et applications pratiques. PhD thesis, 202 p. École Nationale des Ponts et Chaussées, Paris, France,

Haghighi, I., Chevalier, C., Duc, M., Guédon, S. \& Reiffsteck, P. 2013. Improvement of hole erosion test and results on reference soils. Journal of Geotechnical and geoenvironmental engineering 139(2): 330-339.

Herrier, G., Puiatti, D., Bonelli, S., Fry, J.J., Nerincx, N. \& Froumentin, M. 2015. Le traitement des sols à la chaux : une technique innovante pour la construction des ouvrages hydrauliques en terre. ICOLD $25^{\text {th }}$ Congress: 1-21. Stavanger.

Indraratna, B., Muttuvel, T., \& Khabbaz, H. 2009. Modelling the erosion rate of chemically stabilized soil incorporating tensile force-deformation charcacteristics. Canadian $\mathrm{Ge}$ otechnical journal 46: 57-68.

Le Runigo, B., Ferber, V., Cui, Y.J., Cuisinier, O. \& Deneele, D. 2011. Performance of lime treated silty soil under longterm hydraulic conditions. Engineering Geology 118: 2028.
Lim, S.S. 2006. Experimental Investigation of Erosion in Variably Saturated Clay Soils. PhD thesis: 182. The University of New South Wales. Australia.

Luthi, M., Fannin, R.j. \& Milar, R.G. 2012. A modified hole erosion test (HET-P) device. Geotechnical Testing journal, 35(6): 660-664.

McCallister, L. \& Petry, T. 1991. Physical property changes in a lime-teated expansive clay caused by leaching. Transportation Research Board 1295: 37-44.

Mehenni, A. 2015. Comportement hydromécanique et érosion des sols fins traités. PhD thesis: 242. Université de Lorraine. France.

Mehenni, A., Cuisiner, O. \& Masrouri, F. 2016. Impact of lime, cement and clay treatments on the erodibility of compactedsoils. Journal of Materials in Civil Engineering, in press.

Mishra A.K.M., Ohtsubo M., Li, L. \& Higashi T. 2011. Controlling factors of the swelling of various bentonites and their correlations with the hydraulic conductivity of soilbentonite mixtures. Applied Clay Science 52: 78-84.

Mitchell J.K., Hooper, D.R. \& Campanella, R.G. 1965. Permeability of compacted clay, Journal of soil mechanics and foundations division: 41.65

Muttuvel, T. 2008. Erosion rate of chemically stabilized soils incorporating tensile stress-deformation behaviour. $P h D$ thesis: 202, University of Wollongong, Australia.

Pham, T.L. 2008. Erosion et dispersion des sols argileux par un fluide. PhD thesis: 232. Ecole Nationale des Ponts et Chaussées, Paris, France.

Rao, S.M. \& Shivananda, P. 2005. Role of curing temperature in progress of lime-soil reaction. Geotechnical and Geological Engineering 23: 79-85.

Reddi, L.N., Lee, I.M. \& Bonala, M.V.S. 2000. Comparison of internal and surface erosion using flow pump tests on a sand-kaolinte mixture. Geotechnical testing journal 23: 116-122.

Sariosseiri, F. \& Muhunthan, B. 2009. Effect of cement treatment on geotechnical properties of some Washington state soils. Engineering Geology 104: 119-125.

Sivapillaiah, P.V., Sridharan, A. \& Stalin, V.K. 2000. Hydraulic conductivity of bentonite-sand mixtures. Canadian $\mathrm{Ge}$ otechnical Journal 37: 406-413.

Wahl, T. 2010. A comparison of the hole erosion test and jet erosion test. Joint federal interagency conference on sedimentation and hydrologic modeling: 1- 11. Las Vegas.

Wan, C.F. \& Fell, R. 2002. Investigation of internal erosion and piping of soils in embankment dams by the slot erosion test and the hole erosion test. UNICIV Report no.R-412: 358 . Australia.

Wan, C.F. \& Fell, R. 2004. Investigation of rate of erosion of soils in embankment dams. Journal of geotechnical and Geoenviromental engineering 130(4): 373-380. 